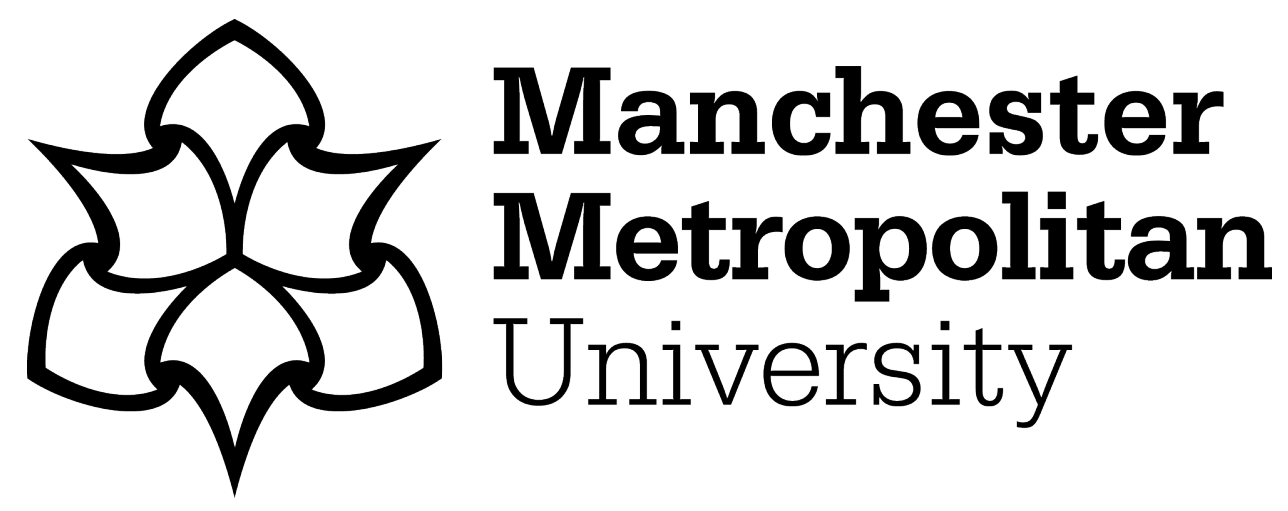

Kayas, Oliver, Hines, Tony, McLean, Rachel and Wright, Gillian H (2019) Resisting government rendered surveillance in a local authority. Public Management Review, 21 (8). pp. 1170-1190. ISSN 1471-9037

Downloaded from: https://e-space.mmu.ac.uk/621818/

Publisher: Taylor \& Francis (Routledge)

DOI: https://doi.org/10.1080/14719037.2018.1544661

Please cite the published version 


\title{
Resisting government rendered surveillance in a local authority
}

\begin{abstract}
The paper illustrates and discusses how the performance management systems in a UK local authority are transformed into a surveillance system. A case study analysis reveals that the surveillance is engendered by central government and enacted by senior managers who conform to policies demanding the introduction of strict performance management systems that dehumanize work processes because employees are deemed untrustworthy. The paper shows that employees resist this government rendered surveillance because they believe it undermines their interests as well as the interests of the public by damaging the quality of the services delivered.
\end{abstract}

Keywords: government, performance management, surveillance, resistance, local authority 


\section{Introduction}

Successive governments in the UK have drawn upon New Public Management to launch an array of initiatives known as the 'local government modernising agenda' which aims to transform the performance of local authorities (Martin 2002; Dooren, Bouckaert, and Halligan 2015). This has changed the public discourse and has resulted in the transformation of local authorities through the principles of the free market, competition, efficiency, and performance management (Broadbent and Guthrie 1992; Martin 2002; Dooren, Bouckaert, and Halligan 2015). Work processes have intensified through the introduction of comprehensive performance management systems that measure and assess individual and organizational performance (Pollitt 2013; Broadbent and Guthrie 1992; Hood 1995; Elston, MacCarthaigh, and Verhoest 2018). Enterprise systems capable of monitoring and measuring individual and organizational performance formed part of this change process and have been adopted throughout local authorities to ensure performance targets are achieved (Frye et al. 2007; Cabinet Office 2011). These policy driven changes intensified with the 2008 financial crisis as a means of reducing costs in local authorities (Pollitt 2010). This is despite diminishing evidence supporting the claim that expanding the use of performance management techniques to measure public sector organizations will improve the service (Fryer, Antony, and Ogden 2009; Micheli and Pavlov 2017).

There is a raft of research examining performance management in the public sector (e.g. Heinrich 2002; Heinrich and Marschke 2010; McAdam, Hazlett, and Casey 2005; Dooren, Bouckaert, and Halligan 2015; Andrews, Boyne, and Enticott 2006; Helden, Johnsen, and Vakkuri 2008; Walker et al. 2011). However, while research focusing on the private sector acknowledges the emergence of surveillance from performance management (Ball and Wilson 2000; Marx 1999; Sewell 2012), there is a dearth of research examining the emergence of surveillance from public-sector performance management systems in local 
authorities. Studying performance management through the rubric of surveillance provides insight into the ways in which working practices are compromised and negatively affect existing levels of control, autonomy, and trust (Ball 2010). It also highlights controversial behavioural issues in the workplace and the broader organizational processes that control access to different levels of the organization itself (Ball 2010; Ball 2001). The purpose of this research is to identify and examine contextual outcomes when public sector performance management systems are adopted within the context of surveillance. This paper contributes by analysing how a performance management system, underpinned by an enterprise system, is transformed into a surveillance system that subjects employees in a local authority to a relentless gaze that judges those who fail to conform to expectations embedded in the gaze by central government. The paper reveals that the effects of surveillance are challenged by employees who resist what they perceive to be ill-conceived changes that undermine their interests whilst damaging the quality of the service delivered to the public.

The paper begins with a discussion of surveillance theory to understand its emergence from performance management systems and to contextualize its appropriation in the workplace. The following section then discusses resistance to provide a lens to analyse how public-sector employees challenge government's gaze. The context of the local authority, hereafter referred to as Council Omega, is then discussed to provide a historical overview of its social, political, and technological context. The methodology section outlines the justification for a qualitative case study analysis of a local authority. The findings are then presented to show how government induced surveillance emerges, how it operates, and how employees resist its effects. The findings are then discussed to outline the paper's contributions. The paper concludes by discussing the implications of the research, its limitations, and future research opportunities. 


\section{Surveillance}

Through the principles of New Public Management successive British governments have incorporated performance management practices derived from the private sector into the public sector (Martin 2002; Diefenbach 2009; Dooren, Bouckaert, and Halligan 2015). As a consequence, the public sector has been reorganized to replace traditional rule-based, authority driven processes with market-based, competition-driven tactics centred around performance management (Soss, Fording, and Schram 2011). This has seen local authorities undergo significant transformation through the adoption of a range of performance management techniques including balanced scorecards, customer satisfaction ratings, efficiency targets, key performance indicators, performance reviews, personal development plans, and quality measures. These techniques involve managers monitoring employees to determine whether they have achieved predefined performance expectations. Micheli and Pavlov (2017) argue that the performance information derived from such performance management techniques can be used in multiple ways. It can be used 'passively' to ensure monitoring, control, and reporting or it can be used 'purposefully' to improve efficiency and effectiveness. It has also been argued that employees expect managers to use performance information to monitor, measure, and evaluate their performance in order to improve efficiency and effectiveness (Marx 1999; Ball and Wilson 2000; Ball 2010). Moreover, if employees are rewarded according to the quantity and quality of their work or if it helps them improve their performance through feedback, then they may accept performance management as a fair practice (Marx 1999). Employees may even perceive performance monitoring as beneficial if it supports organizational goals, maintains workplace safety, or protects organizational activities and information (Fusi and Feeney 2018).

Although workplace surveillance often emerges from performance management systems (e.g. Marx 1999; Ball 2010; Townsend 2005; Mulholland 2004; Gilliom and Monahan 2012; 
Sewell 1998; Sewell and Wilkinson 1992; Sewell and Barker 2006; Sewell, Barker, and Nyberg 2011; Collinson 1999), it differs significantly from performance monitoring. Performance monitoring is considered a less provocative term than surveillance as it does not raise the same political or social-theoretical issues (Sewell, Barker, and Nyberg 2011; Zweig and Webster 2002; Ball 2010). Psychologists tend to use monitoring as a politically neutral term whereas surveillance is used by industrial and organizational sociologists to determine the extent to which employees diverge from expectations embedded in management's gaze (Sewell, Barker, and Nyberg 2011; Ball 2010). Surveillance has dystopian characteristics concerned with power, politics, and resistance and it intensifies the feeling that organizations measure everything that moves in the workplace (Ball 2010; Sewell, Barker, and Nyberg 2011; Agre 1994; Marx 1999). The central idea of workplace surveillance is that when employees are subjected to it they will conform to it by enacting the behaviours desired by those managers watching them whilst identifying with the expectations embedded in the gaze (Iedema and Rhodes 2010). As such, surveillance goes beyond notions of monitoring and evaluating employees to improve performance and is instead underpinned by the notion that employees cannot be trusted to fulfil their contractual obligations (Sewell 2012; Marx 1999; Ball 2010). Surveillance is therefore justified on the grounds that managers need to know whether employees are doing what is expected of them (Sewell 2012). This lack of trust sees employees subjected to a managerial gaze that relentlessly observes, records, and tracks their performance, behaviour, and personal characteristics in real-time as part of the broader organizational process (Ball 2010).

There are different renditions of workplace surveillance emerging from performance management systems that underpin the capitalist enterprise. Bentham (1791) designed the panopticon as an architectural apparatus to control the behaviour of prison inmates through observations coupled with disciplinary punishments. This process involves a few inspectors 
watching many inmates through the apparatus of a prison building. Foucault (1977) extended the panopticon and used it as a metaphor to examine the surveillance and disciplinary power rendered throughout a society's institutions. Its operation involves disciplinary punishments enforced alongside surveillance to create a power relation in which those subjected to its gaze regulate their own behaviour to render observers superfluous. It has been argued that capitalism has seen management adopt the panopticon to scrutinize the workforce, as it is an effective mechanism to control behaviour and improve individual and organizational performance (Fox 1989; Haggerty 2006; Thompson 1967). Despite its significant influence on the field of surveillance, the panopticon is not a comprehensive rubric of surveillance (Haggerty 2006; Lyon 2006). Horizontal (or peer surveillance) differs from the panopticon as it involves employees scrutinising and categorising their peers to create a mutual gaze in which the group punishes those who fail to achieve their expectations (Barker 1993; Sewell 1998). Vertical surveillance involves a supervisor policing the conduct of a subordinate to determine whether their performance is acceptable or not (Sewell 2012, 1998). Selfsurveillance is an increasingly common form of workplace surveillance which involves employees internalising conformity in the absence of a managerial gaze (Iedema and Rhodes 2010). Sewell and Barker (2006) claim that surveillance can be caring or coercive. Surveillance as caring defines employees as subjects who cannot be trusted to fulfil their contractual obligations and therefore need constantly observing to identify any unacceptable behaviour. It has its roots in liberal political economy theory and presents surveillance as a means of "policing the contractual arrangement between principal and agent to minimize opportunistic behaviour such as freeriding' (Sewell, Barker, and Nyberg 2011, 191). The discourse of surveillance as coercion is rooted in 'radical political economy and presents surveillance as means of increasing the subordination of an employee' (Sewell, Barker, and Nyberg 2011, 191). Its purpose is to ensure that employees always work as hard as they can. 
Hence, if you are an employer it is almost always 'good' because it ensures the full efforts of your workforce. However, if you are an employee it is almost always 'bad' because it intensifies work, reduces autonomy, and increases stress.

Surveillance can be rendered through manual observations as in Taylor's (1911) analysis of employee performance in the iron and steel industries or it can be undertaken through information technologies that automatically generate performance information about the workforce. Workplace surveillance has been more widely adopted as new technologies have enabled a broadening of application to sites where hitherto it would not have been used (Iedema and Rhodes, 2010). The diffusion of information technology in the workplace extends notions of surveillance by creating digital infrastructures that extend organizational memories across space and time to provide managers with systems able to observe employees in the past, present, and future (Ball 2006; Lyon 2007; Marx 1985). Zuboff (1988) argues that surveillance technologies are not constrained by the physical arrangement of buildings or the administration needed to record employee performance. These surveillance technologies do not even require an observer as performance information is automatically generated by the digital infrastructure embedded in organizations. According to Soss, Fording, and Schram (2011), performance management systems serve as the core technology for tracking operations and imposing accountability. They guide decisions about renewing or terminating contracts; they provide government officials with a 'yardstick and a prod' for the achievement of goals; and they constitute the major way in which programs are evaluated by government officials. Such technologies have even been used to render performance management systems that not only observe and discipline employees, but also sanction welfare clients for failing to achieve organisational expectations.

This broadening and diversification of new technologies has implications for how we think about surveillance. It also places responsibility with users of technology to be 
consciously aware of the ethics of using surveillance technologies and how they often hide the observer from the observed (West and Bowman 2014). Enterprise systems are one such technology that automatically generate the performance information needed to support and underpin workplace surveillance (Elmes, Strong, and Volkoff 2005; Kayas et al. 2008; Maas, Fenema, and Soeters 2014; Sia et al. 2002; Alvarez 2008). This is enabled through a series of integrated application modules that record and track employees whenever they log on to the enterprise system, providing management with real-time performance information across organizational divisions and geographic boundaries (Kayas et al. 2008). Despite management's attempts to render surveillance technologies designed to eradicate employee hiding places, there are always blind spots where individuals can resist the rationalising nature of surveillance (Sewell 1998).

\section{Resistance}

Resistance can be explained as a struggle against the capitalist labour process to prevent managerial encroachments and to challenge or disrupt their assumptions, discourses, and power relations (Ackroyd and Thompson 1999; Collinson 1994; Fleming and Spicer 2007; Mumby, Thomas, and Martí 2017). Resistance in the public-sector manifests and is instituted in different forms (Broadbent and Laughlin 1998). Torres and Pina (2004) investigated the impact of New Public Management on the modernisation of the public administration to emphasize customer focus, service delivery, quality measures, and information technologies. They found that employees were sceptical of these changes and resisted because they were not convinced by government's intention to undertake actual reforms. McAdam, Hazlett, and Casey (2005) explored the issues emerging from the implementation of performance management activities in a UK public sector organization. They found that the organization relied heavily on a balanced scorecard dominated by the customer perspective at the expense 
of employees. Those employees who felt sidelined resisted the balanced scorecard by actively complaining to management. Ackroyd, Kirkpatrick, and Walker (2007) claim that the extent to which public management reforms are resisted or accommodated varies because of the extent to which professional values and institutions are directed. Elsewhere research has shown how public-sector employees resist the introduction of e-government policies (Ebbers and van Dijk 2007) and new information technologies underpinned by sanctions for poor performance (Timmons 2003a, 2003b). While research examines resistance to public sector performance management systems, there is a lack of research investigating resistance to the surveillance emerging from public sector performance management systems.

Surveillance studies focusing on the workplace show that employees whose interests oppose those who enact surveillance often react through individual or group resistance (Ball 2005; Introna 2000; Kidwell and Sprague 2009; Iedema and Rhodes 2010). Moreover, if employees feel distrusted then it can lead to employee resistance and retaliation (Ball 2010). Research on resistance to surveillance tends to focus on the private sector, especially callcentres which employ extensive surveillance techniques (Ball 2010; Thompson 2003; Thompson and van den Broek 2010). Townsend's (2005) study of an Australian call-centre revealed that employees individually and collectively resisted management's use of electronic surveillance aimed at controlling their behaviour. Mulholland (2004) criticizes managerial accounts of resistance to surveillance in an Irish call-centre for failing to see that the source of conflict was located in the employment relationship and the intensification of work. Through their investigation of an Australian manufacturing firm, Iedema, Rhodes, and Scheeres (2006) introduce the term observance. They use it to understand employee subjugation through disciplinary practices of surveillance and responses to it in terms of compliance and resistance. Factory workers have also been found to foil management surveillance systems intended to micromanage the shop floor (Gilliom and Monahan 2012). 
The discussion above highlights a stream of research examining resistance to public sector performance management systems and a stream of research examining resistance to workplace surveillance in the private sector. There is, however, a lack of research bringing these two streams together to explore resistance to the surveillance emerging from public sector performance management systems.

\section{Context}

This section provides a historical overview of Council Omega's social, political, and technological context to reveal the conditions which influenced its adoption of performance management systems. These factors are important as local authorities are accountable to a wider range of stakeholders than firms in the private sector (Ellwood and Garcia-Lacalle 2015; Fusi and Feeney 2018).

Council Omega is the local authority for a metropolitan borough in the UK. It employs over 10,000 people and serves over 200,000 residents. The Council is composed of councillors who are democratically accountable to residents of their ward. They make decisions within a constitution that provides them with a framework outlining how they must conduct their business. The Council's departments are located on different sites and are divided into 15 services: Jobs; Council Tax; Children and families; Environment; Births, deaths and marriages; Benefits; Bins, rubbish and recycling; Adult social care and support; Housing; Community; Schools; Planning and building control; Libraries; Transport, streets and parking; and Sport and leisure.

Council Omega did not prioritize performance management until the publication of the Gershon Review (2004). Prior to its publication, performance management was not driven by senior management and when it was undertaken it was done on an ad-hoc basis at the behest of individual managers. However, with the Gershon Review's publication, local authorities had to prioritize performance management to achieve its efficiency targets (Elston, 
MacCarthaigh, and Verhoest 2018). The review considered the release of resources through improved efficiencies in public sector activities: 'Auditable and transparent measures of performance are vital if departments are to be effectively held to account for their progress against their efficiency agreement.' It identified back office services as areas where savings could be made by reforming the transactional elements of human resources, finance, and information technology. Efficiency was to be achieved by: increasing the volume of transactions processed electronically thus reducing the cost of data input and corrections; standardising technology to enable the integration and interchange of data; and cutting 84,000 administrative and support posts in the Civil Service. The Gershon Review claimed that the level of information visibility required for monitoring these targets could be provided through integrative information technology that would be used as part of the change programme to improve transactional efficiencies.

Council Omega's legacy systems were unable to generate the performance information needed to monitor and measure individual and organizational-wide performance. The Council therefore decided to purchase an enterprise system to conform to the Gershon Review's demand to utilize integrative information technology and to ensure its performance targets were achieved. The Council considered several vendors eventually committing to SAP's mySAP application, believing it was the only option that would enable them to monitor and measure individual and council-wide performance. The mySAP application was introduced through a phased implementation and became operational in 2005. Today it includes the following modules: Financials; Enterprise Buyer Pro; Customer Service and Plant Maintenance; Property and Estate Management; Records Management for Local Government; and Business Information Warehouse. These different modules support the Council's corporate strategy by automatically generating the performance information needed to determine whether targets have been achieved. Alongside the enterprise system's 
implementation, the Council also introduced annual performance reports outlining their targets for each year, recommendations for achieving them, and arrangements for monitoring and reporting on progress each quarter. These changes ensured Council Omega was aligned with the demands outlined in the Gershon Review.

While the Gershon Review was instrumental in changing the Council's logic to one centred around performance management, after the 2008 financial crisis, a series further of policy reports entrenched notions of performance management to reduce costs (Pollitt 2010). These policy reports include but are not limited to: the Operational Efficiency Programme (HM Treasury 2009); Government Shared Services: A Strategic Vision (Cabinet Office 2011); 50 ways to save: Examples of sensible savings in local government (Department for Communities and Local Government 2012); Measure for measure: Using performance information in tough times (The Association for Public Service Excellence 2012); Efficiency by Design: Stories of Best Practice in Public Bodies (Cabinet Office 2014); Shared service centres (National Audit Office 2016); and Delivering better outcomes for citizens: practical steps for unlocking public value (Barber 2017). The performance management demands outlined in these policy reports were embedded into the Council's annual corporate strategies and performance strategies: 'In line with policy demands we have introduced more stringent and visible targets for improvement and embedded regular and consistent reporting of performance' (Corporate Plan).

\section{Methodology}

This research adopted a qualitative methodology underpinned by the notion that knowledge and our understanding of it is socially constructed (Berger and Luckman 1966; Creswell 2013). This was bound in a case study analysis of a single local authority to understand its particular context in detail (Stake 1995, 2005; Creswell 2013; Flyvbjerg 2006). An 
information orientated selection approach was adopted to maximise the utility of information from the local authority (Flyvbjerg 2006). Whilst not claiming seminal status for this case study, it is a revelatory case, as it gave the researchers the opportunity to investigate government induced surveillance hitherto unobserved in a local authority (Yin 2009). To protect its identity the local authority is referred to as Council Omega. Through the case study analysis, the researchers were able to examine how surveillance emerges from performance management systems and is challenged by employees responding to the changes driven by central government.

Data were collected through interviews and observations of local government employees between March and June 2015. The participants worked in different departments and sites to yield multiple perspectives. Eight managers and 16 workers were interviewed at different levels along the Council's hierarchy. Following the social constructionist approach, the interviews and observations enabled the researchers to explore the perspective of local government employees on performance management and surveillance. The interviews were undertaken in private and comments were restated and discussed to enhance credibility through respondent validation (Creswell 2013). Each interview lasted approximately one hour, was audio-recorded with consent to ensure reliability, and then transcribed. The observations were undertaken during staff meetings, presentations, training sessions, and during informal conversations with employees (Angrosino 2005). Anonymous notes were recorded in a field journal (Patton 2002). The interviews and observations were complemented by an extensive range of documentation to offer insight into Council Omega's sociopolitical context as well as the decisions pertaining to the acquisition and implementation of an enterprise system. This included government reports, council reports, and technical reports. Combining the interviews, observations, and documentation increased the study's credibility, allowing for detailed and rich insights into Council Omega from 
multiple perspectives (Patton 2002). The empirical research was authenticated using approaches suitable for qualitative methods (Creswell 2013; Miles and Huberman 1994). Once the interviews were transcribed, they were used alongside the observations drawing constant comparisons with documentary evidence as well as the extant literature and interpreted by the researchers to enhance the reliability of the analysis. Research rigour was established by following established procedures to ensure credibility, transferability, dependability, and confirmability (Guba and Lincoln 1981).

A thematic analysis was undertaken to identify and interpret patterns in the data (Boyatzis 1998; Braun and Clarke 2006). The multiple sources of data were analysed as it developed to serve as a member checking, confirmation or revision mechanism through which construct validity was established, supporting and illuminating the interpretation of the data (Stake, 1995). This also enabled the researchers to identify interesting areas to pursue as they emerged and to ensure one person did not dominate the theoretical horizon (Gibbs 2007). Drawing upon the empirical data, patterns of experiences were identified and defined (Aronson 1995; Guest, MacQueen, and Namey 2012). All the data pertaining to these patterns were then collated and expounded on (Boyatzis 1998). By relating the empirical data to the literature it enabled the researchers to build valid arguments for choosing themes (Aronson 1995). Two themes emerged from the analysis: the surveillance theme explored the form of surveillance rendered and how it operates; and the resistance theme examined how employees resist the surveillance.

\section{Findings}

\section{Surveillance}

The policy reports outlining the adoption and implementation of performance management systems do not tell the whole story. Employees at different levels in the Council's hierarchy 
claim the performance management systems have been transformed into a surveillance system that relentlessly observes their performance because they are deemed untrustworthy. The Executive IT Manager stated: 'Do we trust staff? It isn't a question of trust. We're under immense pressure [from central government] to improve the productivity of front-line staff whilst reducing staff costs.' In this respect, he is acknowledging the lack of trust because of the need to continually scrutinize individual performance to ensure the Council meets the performance targets defined by central government. This lack of trust was reflected by many of the employees who were interviewed and observed. A Counter Assistant of over 25 years was frustrated by the lack of trust: 'It started years ago [with the Gershon Review]... It's targets, targets, targets all the time. And the recording of the work became the objective, rather than the content of the work. They used to trust us to do our job, but that's gone.' This employee is reminiscing about a time when she was trusted to do her job to a satisfactory level, but with the scrutiny Council Omega now faces from central government, trust is no longer part of the equation. Instead it is about observing and evaluating everything employees do to determine whether performance targets are achieved. A Customer Service Assistant shares this frustration and it is evident when she describes the working environment: 'It's guilty until proven innocent. Management don't trust us, so they just check everything that we do.' This employee is acknowledging the lack of trust and describing how the Council's performance management systems have been transformed into a surveillance system that deems her and her colleagues untrustworthy.

These findings show that employees are observed because they are no longer trusted to do their job. The employees that were interviewed and observed clearly understand that this lack of trust stems from the targets outlined in the Gershon Review as well as the policy reports that followed the 2008 financial crisis. This policy driven change towards intensive performance management was the beginning of the end for managers trusting employees. It 
signifies a new era in which central government forces the Council's managers to give primacy to performance management systems that dehumanize work processes and deem employees untrustworthy. The enterprise system was adopted for this very reason as it provides the digital infrastructure needed to observe and evaluate the performance targets embedded in the Council's performance management policies. Prior to the enterprise system's introduction, the Council's legacy systems were unable to generate performance information about each employee. However, with the enterprise system's introduction, the Council's reorientation towards performance management, and a workforce redefined as untrustworthy, came a form of government induced surveillance that relentlessly generates performance information about each employee on a council-wide scale.

This government induced surveillance is underpinned by the enterprise system and operated by management: 'SAP automatically creates performance data for all our services in real-time and sends it to Service Managers, Line Managers, Department Heads, and the Executive Branch. Being able to monitor performance on a council-wide scale is a dream come true because it means we can understand what's happening in real-time' (Executive HR Manager). The quantitative performance information generated by the enterprise system can be drilled-down from a council-wide perspective to each department within each service area and further down to each employee. This performance information is made available through dashboards and is displayed using numbers and graphs: 'We have a dashboard which displays a range of performance indicators that show, at a glance, how well the Council is meeting its plans' (Head of Policy and Performance). The Director of Community Services elaborates on the dashboard: 'It's traffic-lighted around our performance targets so we can see whether we're on track or not... It provides line managers with a record for each staff member, so they can check their productivity at any point in time'. The dashboard creates high levels of visibility by providing managers with a detailed overview of each employee: 'We know 
exactly where the jobs are up to. SAP provides an action log telling us exactly who the last person to make an adjustment to that job was, what time they went onto the job, and what materials went onto the job. If you're not hitting your targets, you can't hide' (Senior Accountant). This performance information enables Council managers to continuously evaluate each employee to determine whether they have achieved defined performance targets. The surveillance rendered goes beyond the managerial level outlined above, however, as Council Omega must report its performance to central government. All of the employees interviewed understand this point: 'Management need records for the Government showing that the Council's meeting its targets... They use the targets to report to the Government rather than for the benefit of the customer' (Counter Assistant).

The surveillance rendered is overt in nature as employees know they are subjected to a surveillance system that continuously observes and evaluates their performance. The enterprise system automatically informs employees of their performance through onscreen notifications: 'We get a big notification popping up on the screen telling us how many calls we've dealt with and how many we've missed' (Customer Service Officer). An Information Service Officer reinforces this point: 'You've got all these calls coming through and you've got a notification coming up on the screen saying you've missed so many calls during the day. You've got to clear as many as you can because your manager's checking your performance'. Employees also explained that they are given targets pertaining to how many transactions they need to complete and whether they conform to management's expectations: 'Managers run reports to highlight how many tree inspections you've done. It can highlight somebody who isn't pulling their weight, so from my manager's point of view, SAP's the stick to beat somebody with' (Tree Inspector). A Customer Service Officer explains how the enterprise system also records the length of time employees in the contact centre take to complete customer enquiries: 'Management have told us for a pest control enquiry it's only 
four minutes to finish whereas council tax enquires are nine minutes'. Another Customer Service Officer describes how the enterprise system records their performance using their unique login details: 'If you're reporting a highway problem and it hasn't gone through the correct procedure, then it falls back on you. Once you've logged in and saved it, your name's on it, so you've got to get it right'. A Waste Management Officer provides an honest account of how difficult it is to exaggerate his performance: 'It's hard to bull with SAP. Managers can do trails and run reports to see what you've been doing'.

With the Council's reorientation towards performance management and the subsequent emergence of surveillance came the introduction of disciplinary punishments. The Director of Community Services explains why disciplinary punishments were introduced: 'We have to streamline the Council to ensure we're meeting the government's targets as efficiently as we can. Those who fail to achieve their targets are at risk of losing their jobs, but with the scrutiny we're facing, we can't afford to carry anyone'. The Executive HR Manager confirms how the Council's business processes enable managers to identify those who are not performing and subject them to disciplinary punishments: 'SAP's dashboard is great because line managers can use the performance information to identify those staff who aren't performing and who should be let go'. The Council's Corporate Plan outlines the corrective action taken if targets are not achieved: 'We will monitor staff performance continually and take effective action where improvement is needed'. The Corporate Plan also explains the importance of management 'securing planned achievements, taking remedial action where necessary, and ensuring the accountability of staff at all levels'.

The findings from Council Omega reveal that the surveillance is driven by central government's desire to intensify work processes through performance management practices underpinned by an enterprise system that automatically generates performance information about everything an employee does. Senior management enact government's demand to 
continuously observe employees by using the dashboard to make them visible through the relentless recording and tracking of their performance. The surveillance is overt in nature as employees know they are subjected to the gaze of both central government and management. This vertical form of surveillance sees central government and managers observe and police employee performance because they are deemed untrustworthy and so need continually scrutinising to ensure they achieve their contractual agreements. Those who do not achieve the performance expectations embedded in the gaze are dismissed. The following theme reveals how employees resist this surveillance and its effects.

\section{Resistance}

While central government may attempt to impose a surveillance system on Council employees, they are not a docile body that can be easily manipulated. Employees engaged in different forms of resistance against the effects of surveillance. A common form of resistance identified in the Council involves employees ignoring performance targets that undermine service quality. A Customer Service Officer explains how she resists the surveillance by ignoring her targets: 'Last week an elderly man with poor hearing came in who didn't understand his tax bill. Do management really think I'm going to worry about a nine-minute deadline? I was more concerned with helping this poor man, so I spent about half an hour with him.' A Customer Service Assistant in the tourist office also resists by ignoring her performance targets: 'If a customer wants to book a holiday you can't just rush them through it. I often go over my deadline because customers can't always make a decision about their holiday in 10 minutes. My manager's great about it because she doesn't mither you about your targets. She understands that you've got to be sensible'.

The following statement demonstrates how performance targets are ignored because employees prioritize their safety over performance: 'When we're called out to fell a tree 
we're given a time limit that my boss checks, but it's a load of crap. You can't always predict how long it'll take. It could take a few hours, but it could end up taking all day. To be honest, me and the lads don't pay attention to it because we know it's bullshit. Felling a tree can be a dangerous job so we're not going to rush it and risk an accident just because my boss wants to tick a box on his form' (Tree Inspector). Some employees resist their performance targets by complaining to their line manager: 'Me and the girls are always talking about our targets and what a load of rubbish they are. I often speak to my manager and she's sympathetic because she also thinks it's nonsense, but her hands are tied because the Council's got to prove to the government that it's meeting its targets' (Customer Service Officer). Some managers, however, are unsympathetic to their complaints: 'You always get people moaning about their targets, but they've just got to get on with it' (Service Manager).

Another form of resistance identified amongst employees was absenteeism. This was often undertaken by employees who had already been subjected to disciplinary punishments and avoided work to reduce the possibility of being dismissed. The following quote suggests that management are worried that if employees are subject to disciplinary punishments having been off work sick with stress, they could face a backlash from the union: 'One of my colleagues went off sick for two months because he'd been disciplined for missing his targets. He got a doctor's note for stress, so he didn't have to come in for a while. He avoided work so his manager would ease off. Managers know they've got to be careful if someone's been off sick for stress or else it could be a union job. (Counter Assistant). Absenteeism was highlighted by employees throughout the Council: 'A friend of mine went off sick because of the stress. He was struggling with his targets and couldn't hack the pressure... I know quite a few others who've been off sick for stress'.

It is not just employees who resist surveillance. Line managers also resist the effects of surveillance to ensure service quality. One low-level manager explained how he defied senior 
management by reconfiguring the enterprise system so certain tasks could not be observed: 'My team was expected to record every single customer enquiry. If a customer came in and asked for a leaflet, they had to record their name, address, and telephone number. Customers weren't happy about that, so I got SAP changed so you could just click a button to say you'd helped a customer without having to record their personal details.' Some line managers resist by not holding weekly reviews with employees who have missed their performance targets. That is because they are more concerned with ensuring service quality rather than achieving instrumental performance targets. This diminishes surveillance as employees know they are not subject to management's gaze: 'I'm supposed to have regular performance meetings with my team about their targets, but it's not just about how many calls you complete per hour, it's about the quality of the service you deliver. The powers that be don't care about that. If my team's delivering a high-quality service for customers, then I lay off the [performance] meetings. (Line Manager). These findings suggest that managers and employees are not automatons persuaded by the Government's discourse of performance management. Instead, they have the ability to successfully resist surveillance to shape working practices that best serve their interests as well as those of the public.

\section{Discussion}

The paper makes three contributions which are rooted in the context of the public sector and more specifically a single local authority. First, the surveillance is engendered in Council Omega by central government and enacted by senior managers who conform to policies demanding the introduction of strict performance management systems that intensify work processes because employees are deemed untrustworthy. This differs from surveillance in the private sector which emerges from performance management systems induced by managers because employees are deemed untrustworthy. Secondly, the overt and vertical nature of the 
government induced surveillance identified in Council Omega is defined. Thirdly, employees and low-level managers in Council Omega resist government rendered surveillance because they believe it is ill-conceived as it undermines their interests whilst damaging the quality of the service delivered to the public. Each of these contributions is discussed in detail below.

The surveillance identified in Council Omega is consistent with other private sector studies that explain its emergence from performance management systems (Marx 1999; Ball 2010; Townsend 2005; Mulholland 2004; Gilliom and Monahan 2012; Sewell 1998; Sewell and Wilkinson 1992; Sewell and Barker 2006; Sewell, Barker, and Nyberg 2011; Collinson 1999). However, unlike extant research focusing on surveillance in the private sector, the local government employees interviewed and observed in Council Omega are subjected to the powerful demands of central government. Private sector firms do not have to conform to instrumental government demands codified in policies that mandate the rendering of surveillance systems through performance management practices. Senior managers in Council Omega, on the other hand, are duty-bound and must respond to central government and implement their policies (Rose and Miller 2010; Martin 2002; Feiock, Jeong, and Kim 2003). The Gershon Review highlights this point. Prior to its publication, Council Omega did not prioritize performance management practices, nor did it utilize technologies capable of automatically rendering a continuous gaze that relentlessly records and tracks individual performance. These changes were influenced by central government and enacted by senior managers who had to abide by their demands to implement a surveillance system.

The evidence therefore reveals that the government induced surveillance emerged in Council Omega because of the performance targets outlined in the Gershon Review in 2004. While this indicates that the austerity measures outlined in the policy reports that followed the 2008 financial crisis did not influence the initial emergence of surveillance, they certainly entrenched notions of surveillance throughout Council Omega and heightened the need for 
management to dismiss staff to reduce costs. These policy reports are rooted in the principles of New Public Management (Diefenbach 2009; Hartley, Butler, and Benington 2002) and do not explicitly state that surveillance systems need rendering in local authorities. However, surveillance is implicit in the policy reports. They clearly outline the importance of introducing strict performance targets, intensifying work processes, creating high levels of information visibility, improving efficiencies, implementing integrative information technologies with performance management capabilities, and reducing staff costs through dismissals (Diefenbach 2009; Hood 1991). The rational nature of these performance management practices dehumanizes work processes and deems local government employees untrustworthy. Everything employees do therefore needs constantly observing and evaluating to determine whether they are achieving their contractual obligations (Sewell 2012). Under these conditions, local government employees find themselves subjected to a relentless gaze that goes beyond notions of performance management and into a dystopian surveillance system imbued with notions of power and politics (Ball 2010).

The government rendered surveillance identified in Council Omega is deeply dependent on information technology. The enterprise system the Council implemented is crucial to its operation as it automatically records and tracks the performance of every single local government employee. Whenever an employee logs on to the enterprise system their unique login details make them visible to management, as every task they work on has their name assigned to it. The enterprise system underpinning this government induced surveillance supports the claim that political leadership uses technology to exert control over local government (Ahn and Bretschneider 2011). The findings also reveal that the surveillance itself is vertical and aligns with the Council's hierarchy: senior managers, middle-managers, and low-level managers have access to performance information through dashboards allowing them to drill-down from a council-wide perspective to each individual employee. 
Employees, on the other hand, do not have access to dashboards. They are, however, told whether they have deviated from expectations embedded in the gaze by automated notifications displayed by the enterprise system as well as during weekly performance reviews with their line-manager. In this sense, the government induced surveillance identified in Council Omega is overt in nature as employees are aware of the scrutiny they are subjected to: it is not undertaken without their knowledge. Moreover, employees know that the surveillance stems from central government and is enacted by management.

The disciplinary consequences of surveillance are codified in the Council's strategies and are enforced by managers. Those local government employees who deviate from the expectations embedded in the gaze face the possibility of dismissal, which forms part of government's stated plan to reduce staff costs (Gershon Review 2004; Cabinet Office 2014; Department for Communities and Local Government 2012). The decisions around dismissals are informed by quarterly performance reports published by Council Omega and then relayed to central government. This heightens the vertical nature of the surveillance as it involves the government continually observing the Council's performance through reports generated by the enterprise system based on senior management's observations of individual employees. The Council's employees therefore find themselves subjected to government's omnipresent gaze in addition to management's gaze. This differs from the surveillance found in the private sector which tends to only involve managers or other employees from within the firm observing subordinates (e.g. Sewell, Barker, and Nyberg 2011; Bain and Taylor 2000; Ellway 2013; Collinson 1999; Sewell and Wilkinson 1992; Townsend 2005; Iedema, Rhodes, and Scheeres 2006).

Although surveillance is supposed to overcome acts of resistance by illuminating employees and their hiding places (Haggerty and Ericson 2006; Marx 2003), the evidence from the people interviewed and observed suggests that it has not successfully colonized 
employees. The findings from Council Omega are therefore consistent with extant research examining resistance in the workplace. Absenteeism, for example, was identified as a common form of resistance amongst those employees at Council Omega who had been disciplined for failing to achieve the expectations embedded in the gaze (Ackroyd and Thompson 1999; Roscigno and Hodson 2004; Collinson and Ackroyd 2005). Employees at Council Omega rightly believed that by being absent for work-related stress, it would diminish management's ability to observe and dismiss them because they would have an incomplete annual record of their performance. This was exacerbated because both employees and managers knew that the union would intervene in situations where an employee faced dismissal if they had previously been absent for work-related stress. The linemanagers who were interviewed and observed for this research also resisted the surveillance by reconfiguring the enterprise system to prevent senior managers from observing the performance of their team. These technological workarounds demonstrate how the rational nature of the surveillance embedded in the enterprise system was resisted and is not totalising (Alvarez 2008; Ferneley and Sobreperez 2006). Employees at Council Omega also individually and collectively resisted the surveillance by informally complaining to their linemanagers about what they perceived to be instrumental performance demands underpinned by the notion that they cannot be trusted to fulfil their contractual obligations. Some of the managers that were interviewed were sympathetic to these concerns, but others misconstrued their complaints and did not consider them as carefully articulated grievances alerting them to the shortcomings of the surveillance (Prasad and Prasad 2000).

The case study findings go on to reveal that, unlike employees in the private sector who tend to resist the power relations embedded in performance management systems because it undermines their individual or collective interests (Ackroyd and Thompson 1999; Fleming and Spicer 2007), low-level managers and employees in Council Omega also resist on behalf 
of the public. This occurs when performance targets are ignored because employees in the Council believe that it undermines the quality of the service delivered to the public. While the public themselves are not resisting, this reframes resistance as an employee-managementpublic dialectic and not just one centred around employees and management.

\section{Conclusion}

This case study shows how the performance management systems imposed on a local authority are transformed into a surveillance system because central government deem employees untrustworthy. The local government employees interviewed and observed in this case study revealed that the surveillance in Council Omega stems from central government and is enacted by senior managers who constantly scrutinize employees through an enterprise system to ensure they achieve their contractual obligations. The performance information generated by the enterprise system is used to inform decisions around dismissals. These dismissals form a central tenant in government policies aimed at improving efficiencies and reducing costs. However, the local government employees interviewed and observed in Council Omega are not a docile body that easily submit themselves to the subjugation of government and senior management. Policymakers and senior managers therefore need to understand the negative impact these policies could have on the performance of local authorities. While policymakers may have the best of intentions, this case study demonstrates how employees in Council Omega resent the gaze that they have engendered as it deems them untrustworthy. In response, employees and even managers resist the observation of their performance if they believe it undermines their interests or the interests of the public. This strengthens the claim that performance management can be viewed differently depending on how people experience the impact of services (Lowe and Wilson 2017).

A limitation of this paper is that the interviews and observations focus on employees within local government and not central government. This research was dependent on policy 
documents and the views of local government employees to understand central government's perspective. However, this limitation presents a research opportunity. Going forward, research could explore the perspective of policy makers from central government to get at the heart of why they believe public sector employees are untrustworthy and need subjecting to an omnipresent gaze. Another limitation of this research concerns the generalisability of the findings from a single case study. However, this criticism somewhat misses the key point of this research, as it was concerned with particularisation not generalisation (Stake 1995). It is through the detailed study of the particular historical, social, political, and technological conditions in a single local authority that the research was able to identify the specific contextual outcomes that engendered government induced surveillance through performance management.

\section{References}

Ackroyd, Stephen, Ian Kirkpatrick, and Richard M Walker. 2007. "Public Management in the UK and its Consequences for Professional Organization: A Comparative Analysis." Public Management Review 85 (1):9-26.

Ackroyd, Stephen, and Paul Thompson. 1999. Organizational Misbehaviour. London: Sage Publications Ltd.

Agre, Philip E. 1994. "Surveillance and Capture: Two Models of Privacy." The Information Society 10 (2):101-27.

Ahn, Michael J, and Stuart Bretschneider. 2011. "Politics of E- Government: E- Government and the Political Control of Bureaucracy." Public Administration Review 71 (3):41424.

Alvarez, Rosio. 2008. "Examining technology, structureand identity during an EnterpriseSystem implementation." Information Systems Journal 18 (2):203-44.

Andrews, Rhys, George A Boyne, and Gareth Enticott. 2006. "Performance failure in the public sector." Public Management Review 8 (2):273-96.

Angrosino, Michael V. 2005. "Recontextualizing Observation: Ethnography, Pedagogy, and the Prospects for a Progressive Political Agenda." In The Sage Handbook of 
Qualitative Research, edited by Norman K Denzin and Yvonna S Lincoln, 729-45. London: Sage Publications Ltd.

Aronson, Jodi. 1995. "A Pragmatic View of Thematic Analysis." The Qualitative Report 2 (1):1-3.

Bain, Peter, and Phil Taylor. 2000. "Entrapped by the 'electronic panopticon'? Worker resistance in the call centre." New Technology, Work and Employment 15 (1):2-18.

Ball, Kirstie. 2005. "Organization, Surveillance and the Body: Towards a Politics of Resistance." Organization 12 (1):89-108.

. 2006. "Organization, Surveillance and the body: towards a politics of resistance." In Theorizing Surveillance: The panopticon and beyond, edited by David Lyon, 296317. Devon: Willan Publishing.

_. 2010. "Workplace surveillance: an overview." Labor History 51 (1):87-106.

Ball, Kirstie S. 2001. "Situating workplace surveillance: Ethics and computer based performance monitoring." Ethics and Information Technology 3 (3):211-23.

Ball, Kirstie, and David C Wilson. 2000. "Power, Control and Computer-based Performance Monitoring: Repertoires, Resistance and Subjectivities." Organization Studies 21 (3):539-65.

Barber, Michael. 2017. Delivering better outcomes for citizens: practical steps for unlocking public value. London.

Barker, James R. 1993. "Tightening the Iron Cage: Concertive Control in Self Managing Teams." Administrative Science Quarterly 38 (3):408-37.

Bentham, Jeremy. 1791. Panopticon or the Inspection House. London: T. Payne.

Berger, Peter L, and Thomas Luckman. 1966. The Social Construction of Reality: A Treatise in the Sociology of Knowledge. New York: Anchor Books.

Boyatzis, R E. 1998. Transforming Qualitative Information: Thematic Analysis and Code Development. London: Sage Publications Ltd.

Braun, Virginia, and Victoria Clarke. 2006. "Using thematic analysis in psychology." Qualitative Research in Psychology 3 (2):77-101.

Broadbent, Jane, and James Guthrie. 1992. "Changes in the Public Sector: A Review of Recent "Alternative" Accounting Research." Accounting, Auditing \& Accountability Journal 5 (2):3-31.

Broadbent, Jane, and Richard Laughlin. 1998. "Resisting the "new public management": Absorption and absorbing groups in schools and GP practices in the UK." Accounting, Auditing \& Accountability Journal 11 (4):403-35. 
Cabinet Office. 2011. Government Shared Services: A Strategic Vision - July 2011. London.

- 2014. Efficiency by Design: Stories of Best Practice in Public Bodies. Public Chairs Forum, London.

Collinson, David. 1994. "Strategies of Resistance: Power, Knowledge and Subjectivity in the Workplace." In Resistance \& Power in Organizations, edited by John M Jermier, David Knights and Walter R Nord, 25-68. London: Routledge.

Collinson, David, and Stephen Ackroyd. 2005. "Resistance, Misbehavior, and Dissent." In The Oxford Handbook of Work \& Organization, edited by Stephen Ackroyd, Rosemary Batt, Paul Thompson and Pamela S Tolbert, 305-28. Oxford: Oxford University Press.

Collinson, David L. 1999. "'Surviving the Rigs': Safety and Surveillance on North Sea Oil Installations." Organization Studies 20 (4):579-600.

Creswell, John W. 2013. Qualitative Inquiry and Research Design: Choosing Among Five Approaches. 3 ed. London: Sage Publications Ltd.

Department for Communities and Local Government. 2012. 50 ways to save: Examples of sensible savings in local government London.

Diefenbach, Thomas. 2009. "New Public Management in Public Sector Organizations: The Dark Sides of Managerialistic 'Enlightenment'." Public Administration 87 (4):892909.

Dooren, Wouter Van, Geert Bouckaert, and John Halligan. 2015. Performance Management in the Public Sector. 2 ed. Oxon: Routledge.

Ebbers, W E, and J A G M van Dijk. 2007. "Resistance and support to electronic government, building a model of innovation." Government Information Quarterly 24 (3):554-75.

Ellway, Benjamin P W. 2013. "Making it Personal in a call centre: electronic peer surveillance." New Technology, Work and Employment 28 (1):37-50.

Ellwood, Sheila, and Javier Garcia-Lacalle. 2015. "Examining Audit Committees in the Corporate Governance of Public Bodies." Public Management Review 18 (8):113862.

Elmes, Michael B, Diane M Strong, and Olga Volkoff. 2005. "Panoptic empowerment and reflective conformity in enterprise systems-enabled organizations." Information and Organization 15 (1):1-37.

Elston, Thomas, Muiris MacCarthaigh, and Koen Verhoest. 2018. "Collaborative costcutting: productive efficiency as an interdependency between public organizations." Public Management Review. doi: 10.1080/14719037.2018.1438498. 
Feiock, Richard C, Moon- Gi Jeong, and Jaehoon Kim. 2003. "Credible Commitment and Council- Manager Government: Implications for Policy Instrument Choices." Public Administration Review 63 (5):616-25.

Ferneley, Elaine H, and Polly Sobreperez. 2006. "Resist, comply or workaround? An examination of different facets of user engagement with information systems." European Journal of Information Systems 15 (4):345-56.

Fleming, Peter, and André Spicer. 2007. Contesting the Corporation: Struggle, Power and Resistance in Organizations. Cambridge: Cambridge University Press.

Flyvbjerg, Bent. 2006. "Five Misunderstandings About Case-Study Research." Qualitative Inquiry 12 (2):219-45.

Foucault, Michel. 1977. Discipline and Punish: The Birth of the Prison. London: Penguin Books Ltd.

Fox, Stephen. 1989. "The Panopticon: From Bentham's Obsession to the Revolution in Management Learning." Human Relations 42 (8):717-39.

Frye, Doug, Thomas Gulledge, Mary Leary, Rainer Sommer, and Vincent Jimmy. 2007. "Public sector enterprise system implementation." Electronic Government, an International Journal 4 (1):76-96.

Fryer, Karen, Jiju Antony, and Susan Ogden. 2009. "Performance management in the public sector." International Journal of Public Sector Management 22 (6):478-98.

Fusi, Federica, and Mary K Feeney. 2018. "Electronic monitoring in public organizations: evidence from US local governments." Public Management Review 20 (10):1465-89. Gershon Review. 2004. Releasing resources to the front line: Independent Review of Public Sector Efficiency. London.

Gibbs, Graham R. 2007. Analyzing Qualitative Data. London: Sage Publications Ltd. Gilliom, John, and Torin Monahan. 2012. "Everyday resistance." In Routledge Handbook of Surveillance Studies, edited by Kirstie Ball, Kevin Haggerty and David Lyon. Oxon: Routledge.

Guba, E G, and Y S Lincoln. 1981. Effective Evaluation: Improving the Usefullness of Evaluation Results through Responsive and Naturalistic Approaches. San Francisco: Jossey-Bass Publishers.

Guest, Greg, Kathleen M MacQueen, and Emily E Namey. 2012. Applied Thematic Analysis. London: Sage Publications Ltd. 
Haggerty, Kevin D. 2006. "Tear down the walls: on demolishing the panopticon." In Theorizing Surveillance: The panopticon and beyond, edited by David Lyon, 23-45. Devon: Willan Publishing.

Haggerty, Kevin D, and Richard V Ericson. 2006. "The New Politics of Surveillance and Visibility." In The New Politics of Surveillance and Visibility, edited by Kevin D Haggerty and Richard V Ericson, 3-34. Toronto: University of Toronto Press Incorporated.

Hartley, Jean, Michael J R Butler, and John Benington. 2002. "Local Government Modernization: UK and Comparative Analysis from an Organizational Perspective." Public Management Review 4 (3):387-404.

Heinrich, Carolyn J. 2002. "Outcomes-Based Performance Management in the Public Sector: Implications for Government Accountability and Effectiveness." Public Administration Review 62 (6):712-25.

Heinrich, Carolyn J, and Gerald Marschke. 2010. "Incentives and their dynamics in public sector performance management systems." Journal of Policy Analysis and Management 29 (1):183-208.

Helden, G Jan van, Åge Johnsen, and Jarmo Vakkuri. 2008. "Distinctive research patterns on public sector performance measurement of public administration and accounting disciplines." Public Management Review 10 (5):641-51.

HM Treasury. 2009. Operational Efficiency Programme: final report. Surrey.

Hood, Christopher. 1991. "A public management for all seasons?" Public Administration 69 (1):3-19.

_. 1995. "The "New Public Management" in the 1980s: Variations on a theme." Accounting, Organizations and Society 20 (2/3):93-109.

Iedema, Rick, and Carl Rhodes. 2010. "The Undecided Space of Ethics in Organizational Surveillance." Organization Studies 31 (2):199-217.

Iedema, Rick, Carl Rhodes, and Hermine Scheeres. 2006. "Surveillance, Resistance, Observance: Exploring the Teleo-affective Volatility of Workplace Interaction." Organization Studies 27 (8):1111-30.

Introna, Lucas D. 2000. "Workplace surveillance, privacy, and distributive justice." Computers and Society. doi: 10.1145/572260.572267.

Kayas, Oliver George, Rachel McLean, Tony Hines, and Wright H Gillian. 2008. "The panoptic gaze: Analysing the interaction between enterprise resource planning 
technology and organisational culture." International Journal of Information Management 28 (6):446-52.

Kidwell, Roland E, and Robert Sprague. 2009. "Electronic surveillance in the global workplace: laws, ethics, research and practice." New Technology, Work and Employment 24 (2):194-208.

Lowe, Toby, and Rob Wilson. 2017. "Playing the Game of Outcomes-based Performance Management. Is Gamesmanship Inevitable? Evidencefrom Theory and Practice." Social Policy and Administration 51 (7):981-1001.

Lyon, David. 2006. "The search for surveillance theories." In Theorizing Surveillance: The panopticon and beyond, edited by David Lyon, 3-20. Devon: Willan Publishing.

- 2007. Surveillance Studies: An Overview. Cambridge: Polity Press.

Maas, Jan-Bert, Paul C van Fenema, and Joseph Soeters. 2014. "ERP system usage: the role of control and empowerment." New Technology, Work and Employment 29 (1):88103.

Martin, Steve. 2002. "The Modernization of UK Local Government: Markets, Managers, Monitors and Mixed Fortunes." Public Management Review 4 (3):291-307.

Marx, Gary T. 1985. "I'll be watching you: Reflections on new surveillance." Dissent 32 (1):26-34.

1999. "Measuring Everything That Moves: The New Surveillance at Work " In The Workplace and Deviance, edited by I Simpson and R Simpson. Greenwich, CT: JAI Press.

_. 2003. "A Tack in the Shoe: Neutralizing and Resistingthe New Surveillance." Journal of Social Issues 59 (2):369-90.

McAdam, Rodney, Shirley-Ann Hazlett, and Christine Casey. 2005. "Performance management in the UK public sector: Addressing multiple stakeholder complexity." The International Journal of Public Sector Management 18 (3):256-73.

Micheli, Pietro, and Andrey Pavlov. 2017. "What is performance measurement for? Multipleuses of performance information within organizations." Public Administration:1-17. doi: 10.1111/padm.12382.

Miles, Mathew B, and Michael Huberman. 1994. An expanded sourcebook: Qualitative data analysis. London: Sage Publications Ltd.

Mulholland, Kate. 2004. "Workplace resistance in an Irish call centre: slammin', scammin' smokin' an' leavin'." Work, employment and society 18 (4):709-24. 
Mumby, Dennis K, Robyn Thomas, and Ignasi Martí. 2017. "Resistance Redux." Organization Studies 38 (9):1157-83.

National Audit Office. 2016. Shared service centres: (HC 16, Session 2016-17).

Patton, Michael Quinn. 2002. Qualitative Research and Evaluation Methods. 3 ed. London: Sage Publications Ltd.

Pollitt, Christopher. 2010. "Cuts and reforms-Public services as we move into a new era." Society and Economy 32 (1):17-31.

_. 2013. "The Evolving Narratives of Public Management Reform: 40 years of reform white papers in the UK." Public Management Review 15 (6):899-922.

Prasad, Pushkala, and Anshuman Prasad. 2000. "Stretching the Iron Cage: The Constitution and Implications of Routine Workplace Resistance." Organization Science 11 (4):387-403.

Roscigno, Vincent J, and Randy Hodson. 2004. "The Organizational and Social Foundations of Worker Resistance." American Sociological Review 69 (1):14-39.

Rose, Nikolas, and Peter Miller. 2010. "Political power beyond the State: problematics of government." The British Journal of Sociology 61 (s1):271-303.

Sewell, Graham. 1998. "The Discipline of Teams: The Control of Team-based Industrial Work through Electronic and Peer Surveillance." Admtnistrattve Science Quarterly 43 (2):397-428.

_. 2012. "Organization, employees and surveillance." In Routledge Handbook of Surveillance Studies, edited by Kirstie Ball, Kevin Haggerty and David Lyon. Oxon: Routledge.

Sewell, Graham, and James R Barker. 2006. "Coercion versus care: using irony to make sense of organizational surveillance." Academy of Management Review 31 (4):93461.

Sewell, Graham, James R Barker, and Daniel Nyberg. 2011. "Working under intensive surveillance: When does 'measuring everything that moves' become intolerable?" Human Relations 65 (2):189-215.

Sewell, Graham, and Barry Wilkinson. 1992. "'Someone to watch over me': Surveillance, discipline and the just-in-time labour process." Sociology 26 (2):271-89.

Sia, Siew Kien, May Tang, Christina Soh, and Wai Fong Boh. 2002. "Enterprise Resource Planning (ERP) Systems as a Technology of Power: Empowerment or Panoptic Control." Database for Advances in Information Systems 33 (1):23-37. doi: $10.1145 / 504350.504356$. 
Soss, Joe, Richard Fording, and Sanford F Schram. 2011. "The Organization of Discipline: From Performance Management to Perversity and Punishment." Journal of Public Administration Research and Theory 21 (suppl_2):i203-i32.

Stake, Robert E. 1995. The Art of Case Study Research. London: Sage Publications Ltd.

—. 2005. "Qualitative Case Studies." In The Sage Handbook of Qualitative Research, edited by Norman K Denzin and Yvonna S Lincoln, 443-66. London: Sage Publications Ltd.

Taylor, Frederick Winslow. 1911. The principles of scientific management. New York: Harper \& Brothers Publishers.

The Association for Public Service Excellence. 2012. Measure for measure: Using performance information in tough times. Manchester.

Thompson, E. P. 1967. "Time, Work-Discipline, and Industrial Capitalism." Past and Present 38:56-97.

Thompson, Paul. 2003. "Fantasy Island: a Labour Process critique of the 'age of surveillance'." Surveillance \& Society 1 (2):138-51.

Thompson, Paul, and Diane van den Broek. 2010. "Managerial control and workplace regimes: an introduction." Work, employment and society 24 (3):1-12.

Timmons, Stephen. 2003a. "A failed panopticon: surveillance of nursing practice via new technology." New Technology, Work and Employment 18 (2):143-53.

_. 2003b. "Nurses resisting information technology." Nursing Inquiry 10 (4):257-69.

Torres, LourDes, and Vicente Pina. 2004. "Reshaping Public Administration: The Spanish Experience Compared to the UK." Public Administration 82 (2):445-64.

Townsend, Keith. 2005. "Electronic surveillance and cohesive teams: room for resistance in an Australian call centre?" New Technology, Work and Employment 20 (1):47-59.

Walker, Richard M, Gene A Brewer, George A Boyne, and Claudia N Avellaneda. 2011. "Market Orientation and Public Service Performance: New Public Management Gone Mad?" Public Administration Review 71 (5):707-17.

West, Jonathan P, and James S Bowman. 2014. "Electronic Surveillance at Work: An Ethical Analysis." Administration \& Society:1-24. doi: 10.1177/0095399714556502.

Yin, Robert K. 2009. Case Study Research: Design and Methods. 4 ed. London: Sage Publications Ltd.

Zuboff, Shoshana. 1988. In the Age of the Smart Machine: The Future of Work and Power. USA: Basic Books Inc. 
Zweig, David, and Jane Webster. 2002. "Where is the line between benign andinvasive? An examination of psychologicalbarriers to the acceptance of awarenessmonitoring systems." Journal of Organizational Behavior 23 (5):605-33. 